\title{
FLOOD PLAIN EVALUATION IN THE GANGA-BRAHMAPUTRA DELTA: A TECTONIC REVIEW
}

\author{
*Jha, V.C. and Bairagya, H.P. \\ DOI:http://dx.doi.org/10.4314/ejesm.v4i3.3 \\ Received September12 $2^{\text {th }} 2011$; accepted October $4^{\text {th }} 2011$
}

\begin{abstract}
The world's largest Ganga-Brahmaputra Delta has been characterized by an interesting and complicated tectonic background and geomorphic history. Actually the delta is situated in the southern part of Bengal Basin in Eastern India. The Bengal Basin as well as Ganga-Brahmaputra Delta, is a significant low flat terrain which has elevation of 10-30m above the m.s.l. Delta building processes are active over southern part, while the Northern part shows the characteristics of a mature landscape. The Delta is named as 'khadar'. The eastern part of Indo-gangetic plain is joined with the lower Brahmaputra plain and helps to form the delta. The delta has passed through a long evolutionary history and phases i.e. early Triassic, Jurrassic, Cretaceous, Oligocene, Miocene and Holocene. The Basin contains silt, clay, several minerals, metals etc. The delta is mainly created by the deposition after the sea-transgression in the upper cretaceous period. The mineralogy is dominated by detrital quartz, some feldspar and minor amounts of carbonates illite and kaolinite. Therefore its geological setup and the tectonic events and their influence on the geomorphic features particularly the flood-plain have been thoroughly investigated and presented in this paper.
\end{abstract}

Keywords: Flood Plain, Ganha-Brahamputra Delta, Geological Formations, Tectonic History, Sea-transgression.

\section{Introduction}

The Geological set up of an area helps to interpret the geonomic aspects directly and sociocultural aspects indirectly. The Bengal basin in India is concerned with large and extensive flood-plain characterized by agricultural and agro-based socioeconomic activities. The Geological set and the tectonic events in the Bengal Basin indicates the geomorphic characteristics are the main factor which forms the most fertile land concentrating the world's largest population center. Most of the parts of the Ganges-Brahmaputra delta are located within, or seaward, of Bangladesh a country of some 140 million inhabitants with a population density approaching 1,000 persons per $\mathrm{km}^{2}$. The southwest sector of the delta extends into India, covering an area of approximately $25,000 \mathrm{~km}^{2}$, or about $22 \%$ of the sub-aerial surface. People living on the delta have adapted to the harsh realities of frequent flooding and land loss and/or gain characteristic of lowland deltas, but they face an uncertain future as development of river control structures, global sea-level rise, and climate change threaten to alter the dynamic balance between sediment supply, subsidence, and sea level in various regions of the delta. To study the evolutionary history of the Bengal basin the study of Indian peninsula is essential.

\section{Location}

The Bengal delta is situated in the eastern part of India and in the Southern part of undivided Bengal. The delta is centrally located in between the latitude of $21^{\circ} 43^{\prime} 30^{\prime \prime} \mathrm{N}$ to $24^{0} 50^{\prime} 20^{\prime \prime} \mathrm{N}$ and longitude of $87^{0} 49^{\prime} 17^{\prime \prime} \mathrm{E}$ to $91^{0} 211^{\prime} 00$ "E.In the eastern part of the delta the Chattagram Hill region of Bangladesh is situated. Barendrabhumi is situated in the Northern part of the delta. Rarh, the dissected part of eastern Chottanagpur Plateau, is situated in the western part of the Delta. The geological background of India is to be evaluated primarily to clear the concept about the formation of the delta.

\section{Geological Divisions of India}

The most salient facts with regard to both the Physical Geography and Geology of the Indian region is that, it is composed of three distinct units of earth surface-

Department of Geography, Visva Bharati, Santiniketan, West Bengal, India

Corresponding author e-mail:vcjha@asia.com 


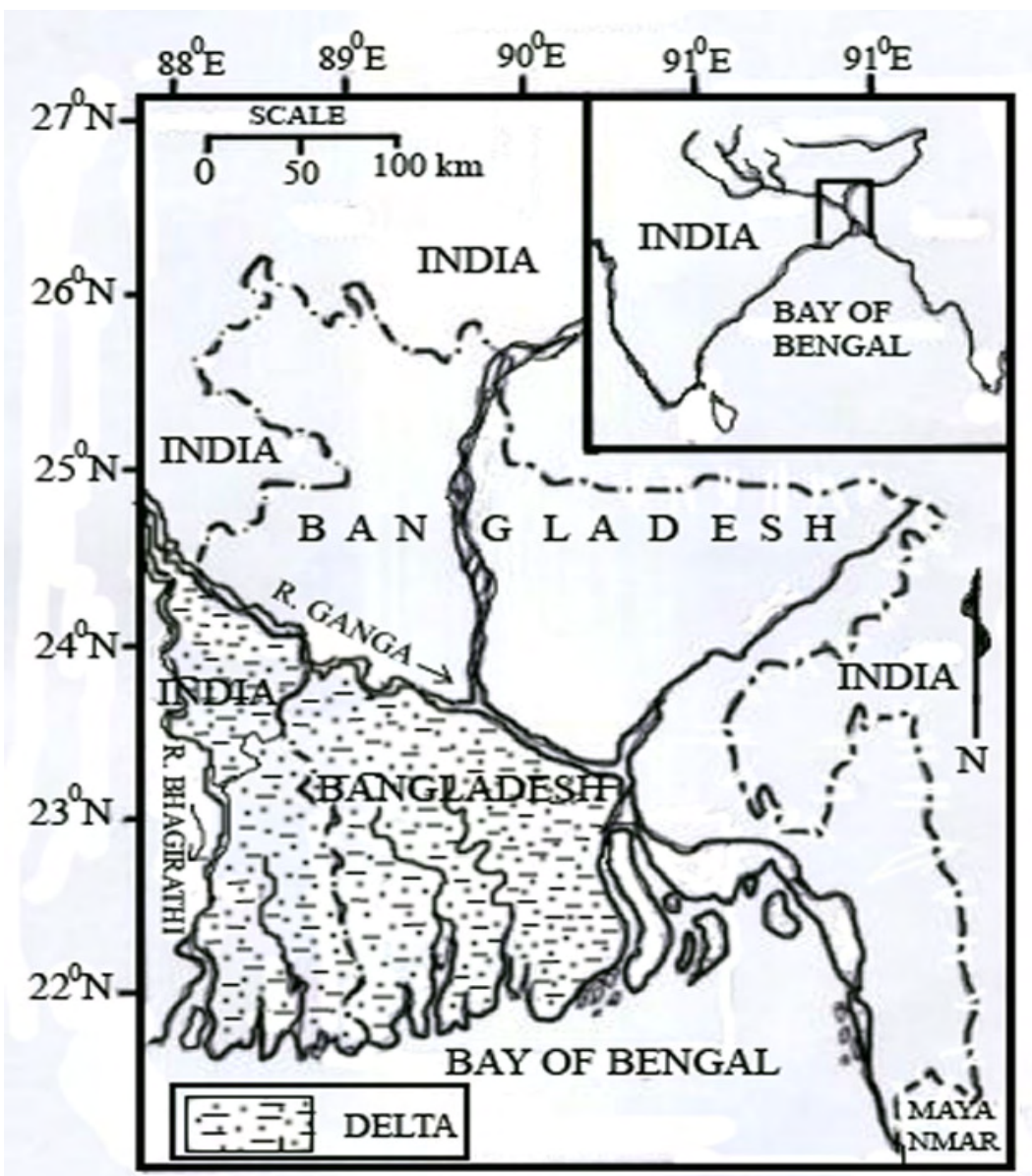

Fig.1: Location of the Study-Area

1) Peninsula

2) Extra peninsula

3) Indo-Gangetic plain

(i) Peninsula - The triangular plateau of Peninsula (i.e. the Deccan, south of the Vindhyas), with the island Srilanka.

(ii) Extra Peninsula - The mountainous region of the Himalayas which borders India to the west, north and east, including the countries of Afganistan, Baluchistan, and hill-tracts of Burma, known as Extra Peninsula.

(iii) Indo-Gangetic plain- The great Indo-Gangetic plain of Bengal separating the two former areas and extending from the valley of the Indus in Sindh to that of the Brahmaputra of Assam(Wadia,1975).

The Ganga Brahmaputra Delta is a significant part of Indo-Gangetic plain and Murshidabad District is situated in the northern portion of the region.

\section{Formation of the Gangetic Plain}

The Earth's crust, according to the theory of 'plate tectonic', is divided into no. of plates, each of which behaves as the relatively rigid unit. These plates shift due to sea floor spreading prior to subduction in early Triassic period (225-190 million years ago) most of the earth's land area was a single continental mass, called 'Pangea' which was surrounded by an ocean called 'Panthalasa'. About 200 million years ago, 'Panthalasa' splited first into two masses known as 'Lauresia' \& 'Gondowana'. Lauresia' later broke into 3 masses, the western most formed N. America \& other two the 'Eurasia' and the 'East Asia' formed most of the Asian \& European land mass.

In the Jurrassic period (194-136 million yrs ago), the Indian portion of the Gondowana mass split and began to move north toward Asia. The IndiaAustralian portion of Gondowana was believed to be on the same plate, known as the Indo-Australian plate. 
The Indian and the Australian portions were split along the longitude of $90^{\circ} \mathrm{E}$, during late Cretaceous period (75-65 million yrs ago), due to the movement of two portions in opposite directions. The Indian portions of Gondowana land moved northward relatively fast and collide with the Euro-Asian (Hercynian) and the East- Asian (Cathaysian) plates in the Eocene period (54-38 million yrs ago). The collision was on such a tremendous scale that the Indian plate intruded $2000 \mathrm{~km}$ into the Cathaysian plate, this resulted the upliftment of the Himalayan system and the Tibetan plateau. From 45 million years ago to the present time, the India plate has rotated $33^{0}$ counter clockwise with the motion relative to Asian plate has changed from predominantly north-east to more northerly accompanied by $50 \%$ reduction in velocity (Uddin and Lundberg, 2003).

In the late Oligocene (26 million yrs ago), northeast ward drift of the Indian plate laid to the consumption of the oceanic crust that existed between the eastern edge of the Indian plate and the Indo-Burmese subduction zone; oblique subduction of Indian plate allowed gradual continental convergence and zipper like closure in the intervening ocean basin (Tethys) along a north-south axis. However a small remnant basin still exited as a triangular area near the southern trip of the Indo Burmese continental suture known as Faridpur through (Bangladash) continuing south-west ward along the sub-marine canyon 'swatch of no ground' (Sarkar, 2001).

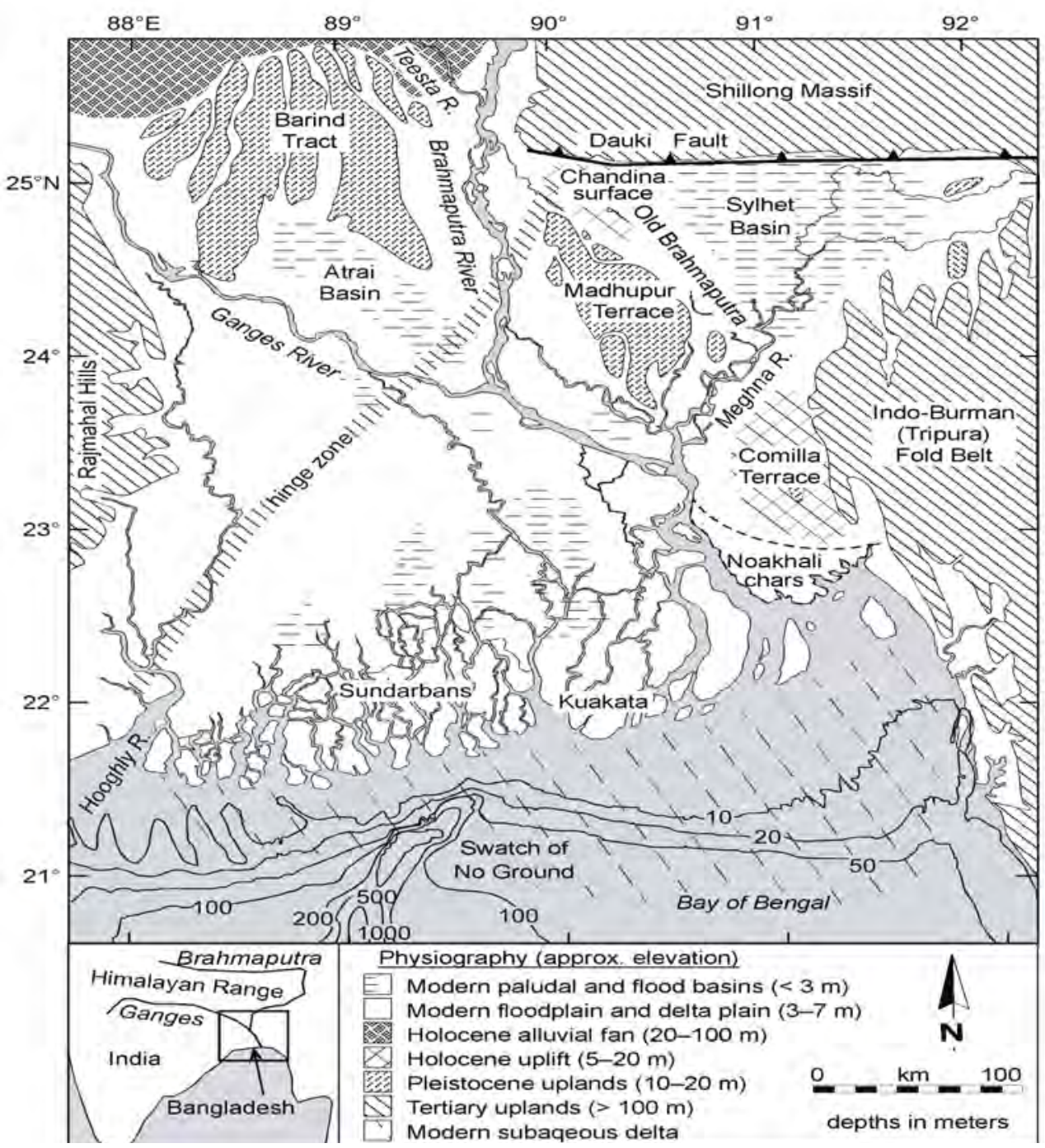

Fig.2 Physiography of the Study-area (Source: SEPM Special Publication No. 83) 


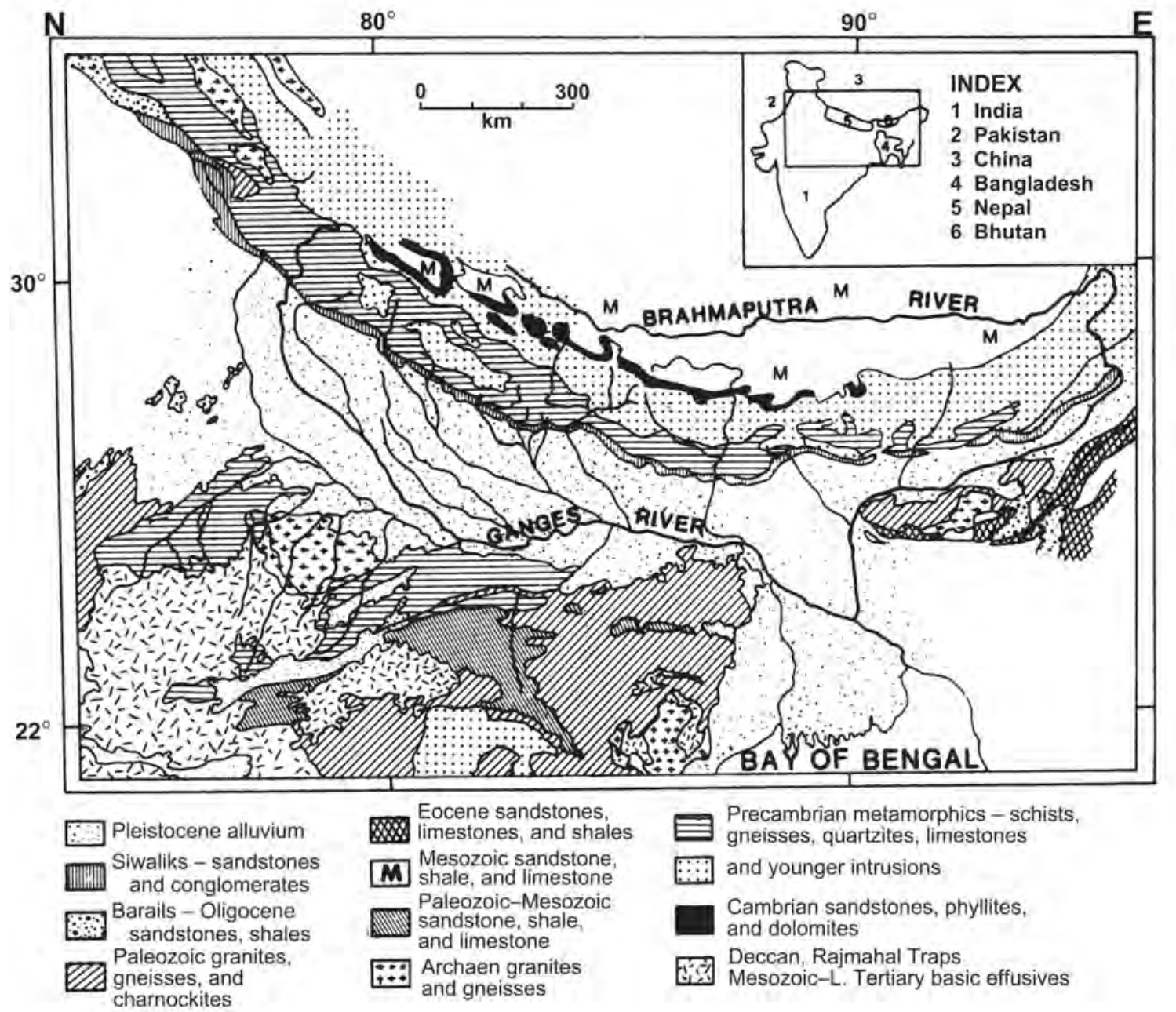

Fig.3 Geological Formations (Source: SEPM Special Publication No. 83)

\section{Formation of Bengal Plain: A Part of Indo- Gangetic Plain}

Geologically the Bengal Basin is bordered directly by the Precambrian Shillong Massif and Indian Shield to the north and west, and the Neogene Tripura Fold Belt to the east (Fig. 1). The tectonic activity of the basin has influenced riverine sediment distribution of all parts of the margin. Because of the ongoing collision of the Burmese plate overriding the eastern margin of the Indian continent and its adjacent oceanic crust, the Bengal Basin has been subsiding sincethe Eocene (Alam, 2003).

While most of the world's major rivers enter the ocean along passive continental margins, the Ganges and Brahmaputra originate in the still rising Himalayan orogenic belt and reach the sea across the tectonically active Bengal Basin. Despite its proximity to the Himalayan foredeep, though, the Bengal Basin is situated seaward of the foreland hinge on a classic trailing-edge margin. Nevertheless, the margin is deformed within this complex, but poorly understood, tectonic setting. As evidence of this activity, the Bengal Basin is bordered directly by the Precambrian Shillong Massif and Indian Shield to the north and west, and the Neogene Tripura Fold Belt to the east (Fig. 1). The tectonic activity of the basin has influenced riverine sediment distribution of all parts of the margin. Because of the ongoing collision of the Burmese plate overriding the eastern margin of the Indian continent and its adjacent oceanic crust, the Bengal Basin has been subsiding since the Eocene (Alam, 2003). The Eocene carbonate platform formed at the drifting Indian plate can easily be traced in seismic records and boreholes from a few hundred meters depth on the Indian side, dipping southeast wards under deltaic sediments to depths of about $6 \mathrm{~km}$ (Reimann and Hiller, 1993). 
The thickness of deltaic sediments overlying the oceanic crust in the central and eastern basin may reach up to $20 \mathrm{~km}$. Long-term tectonic subsidence in the eastern and southern basin of 1-2 mm y-1 has been balanced by the high sediment supply from Himalayan erosion (Alam, 1996). The approximate transition of the Indian continent to oceanic crust, which acts as a hinge line, is marked by high gravity and magnetic anomalies (Iman and Shaw, 1985). Except for two possibly fault-bounded terraces that are elevated 3-15 $\mathrm{m}$ above the Holocene alluvium (Madhupur and Barind; Fig. 1), the basin surface over which the Ganges and Brahmaputra migrate is of low relief, dipping gently seaward from a mean elevation of $10-15 \mathrm{~m}$ in the upper delta plain. At the coast, the Holocene Ganges-Brahmaputra delta has prograded across a broad front $(380 \mathrm{~km})$ bordered by the Hoogly River in the west (India) and the Tripura fold belt of eastern Bangladesh. The Bengal basin, a complex foreland basin, south of the eastern Himalayas, exhibits dramatic variability in Neogene sediment thickness that reflects a complicated depositional and tectonic history. This basin originally formed as a trailing margin situated at the S.E of the Indian continental crust complicated by convergence with Asia to the north and oblique convergence with the Burma to the east. Newly compiled isopatch data and previously reported seismic data show evidence of thickening of basin fill toward the south, opposite of the pattern typically sea in foreland basin(isopatch map of Oligocene, sequence after Neogi,1987 and Sarkar, 2001).

Isopatch data shows that there is considerable vertical relief along the base of the Miocene statigraphic sequence, probably due to underlying basin faulting caused by focused deltaic sedimentation and associated crustal flexure. In contrast when view in east-west profile basin shape is more typical of a foreland basin with strata thickening eastward the Indo-Burman ranges which reflect east-west convergence with South-east Asia. (Uddin and Lundberg, 2003).

The collision of the Indian plate with the Tibetan plate and with the Burmese plate in the Miocene resulted in a rapid switch in sedimentation pattern in the Bengal Basin. The basin structure and sedimentation were both strongly influenced by the collision pattern of the plates and by the uplifts of the Himalayas. With the Miocene collision of the Indian plate there was a change from flysch to molasses sedimentation. The present-day basin configuration with the Ganges - Brahmaputra Delta and the Bengal deep sea fans of the south was established in the Pliocene (Alam, 1989).

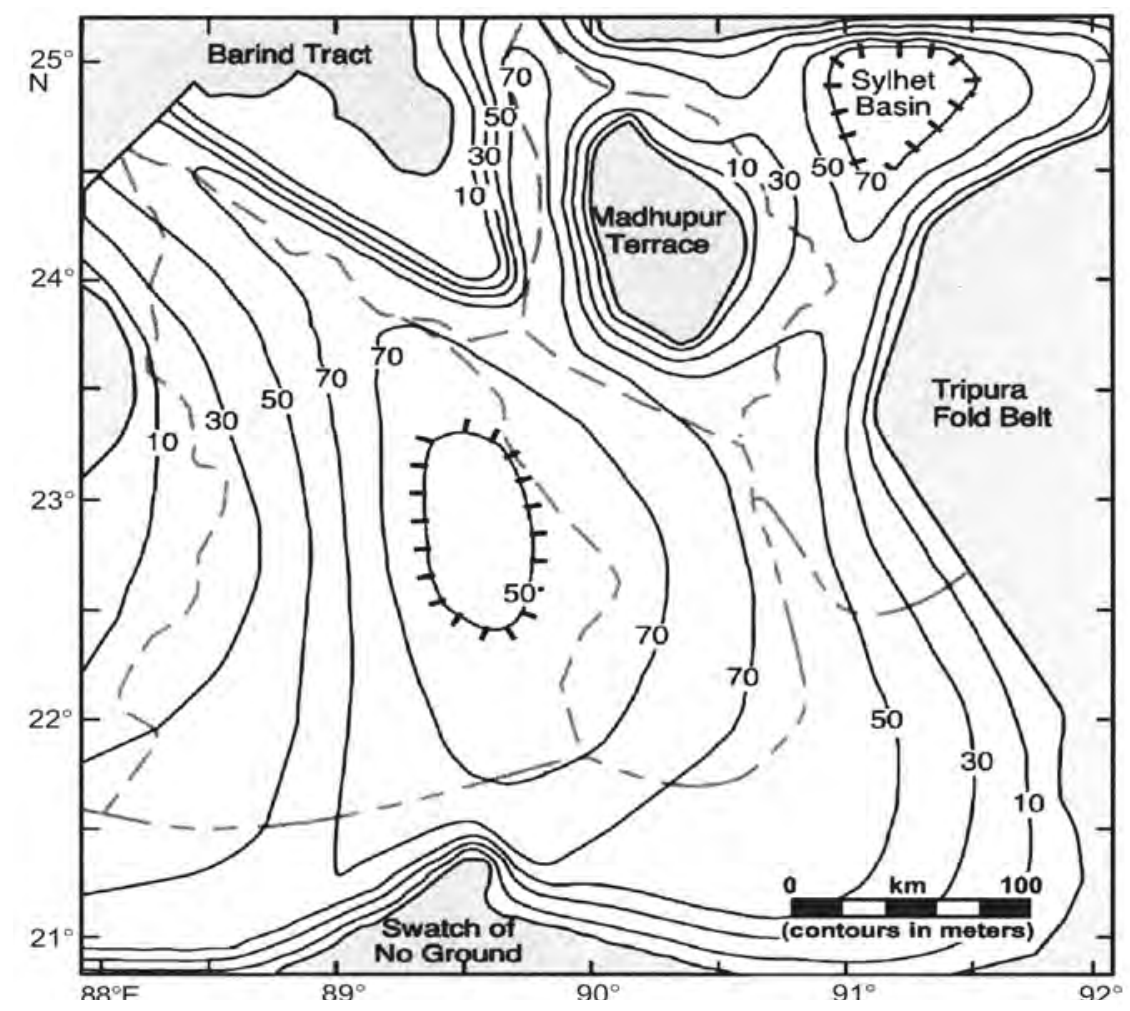

Fig.4 Relief (Source: SEPM Special Publication No. 83) 


\section{Sedimentation in Bengal Basin}

The Bengal basin lies on the eastern side of the Indian sub-continent and occupied in the northern part of Bengal Geosynclines. The sedimentation started with the break up of Gondowana land at the late Mesozaic period and continues up to Holocene or Recent periods. Cretaceous fluvial and deltaic sedimentation was slowly taken over by open marine and deep-sea fan sedimentation under shallow water. This was actually succeeded by a downward movement and associated marine transgression in the upper cretaceous period (Alam, 1989).

At the beginning of Cenozoic Era, a phase of marine regression occurred. It was followed by a pronounced transgressional phase during the Eocene period. There was wide spread marine regression followed by another fresh marine activity during late Oligocene and Early Miocene. In Early Miocene (20 million yrs ago) under thrusting began along the Himalayan chain. Due to flexural down warp of Bengal continental lithosphere underneath the IndoBurma Thrust belt, Bengal continental lithosphere took the shape of a foreland basin (Biswas and Agarwal, 1992). Due to its position in between one of the world's subduction faults in the north and a major transform fault, the Bengal basin is an active tectonic region. Thus some areas within this basin are still sinking (Sarkar, 2001). By the mid-Eocene the basin was witnessed the maximum marine transgression and most of the stable shelf was in carbonate regime as part of the extended Tethyan carbonate shelf. The deeper part of the basin was dominated by deep seafan sedimentation bed by clastic turbidities from the northern with limited carboniferous turbidities from the shelf (Alam, 1996).

Since Neocene the Bengal basin has been filled up with sediments washed down from the highlands from three sides, particularly by the BrahmaputraGanga river system. The total sediment filling during the Cenozoic, even for the limited area of the basin lying inside the Indian territory, is estimated to be over $315,000 \mathrm{~km}^{3}$ (Biswas and Agarwal, 1992). In the late Pleistocene, the sea receded and a brackish water condition prevailed. The area comes under fluvial domain during the Holocene period. The Ganges and Brahmaputra Rivers currently contribute about a billion tons $(1012 \mathrm{~kg})$ of sediment annually to the Bengal Basin, and over the Holocene these sediments have built a deltaicfeature with a subaerial surface area of $110,000 \mathrm{~km}^{2}$. The modern delta continues offshore as a prograding clinoform, extending $125 \mathrm{~km}$ across the continental shelf from the river mouths, and about $250 \mathrm{~km}$ along shelf from the eastern coast of Bangladesh west to the "Swatch of No Ground" submarine canyon, roughly at the border of India and Bangladesh. Thus, the total area of the combined subaerial and submarine delta is about $140,000 \mathrm{~km}^{2}$, an area roughly equivalent to the size of Britain (Kuhel, 2005).

\section{Formation of Bengal Delta: A Part of Bengal Basin}

The Bengal basin, the largest fluvio-deltaic sedimentary on Earth is located in Bangladesh and three eastern states of India. Sediment accumulates from the Ganges, Brahmaputra, Meghna (GBM) river system and is dispersed into the Bay of Bengal, forming the largest sub marine fan in the world. The delta as well as the basin is located in the Himalayan foreland at the junction of Indian, Eurasian and Burmese plate. Basin sediments overlie Gondowana basement and vary in thickness from a few kilometers on the stable shelf to more than $16 \mathrm{~km}$ in foredeep. The basin was initiated at this break up of Gondowana land in the late Mesozoic and evolved through the formation of the proto GangaBrahmaputra-Meghna (GBM) delta to the present delta staring around $10.5 \mathrm{Ma}$. The present configuration of Bengal delta is a late Pleistocene to recent feature (Mukherjee, Fryar and Thomus, 2008).The beds are nearly horizontal, low dipping toward the east and south-east.

The present day Geomorphology is dominated by the extensive Holocene Ganga-Brahmaputra flood plain of delta. The vertical succession of delta plain can be classified in five units on the basis of different grain size which reflected different depositional environment. The initiation of the modern delta as the onset of the pleistocene glacial maximum and its evolution to the present configuration are intricately related to Holocene fluvio-dynamic processes, ustatic sea level changes and tectonic movements (Mukherjee et al., 2008). 


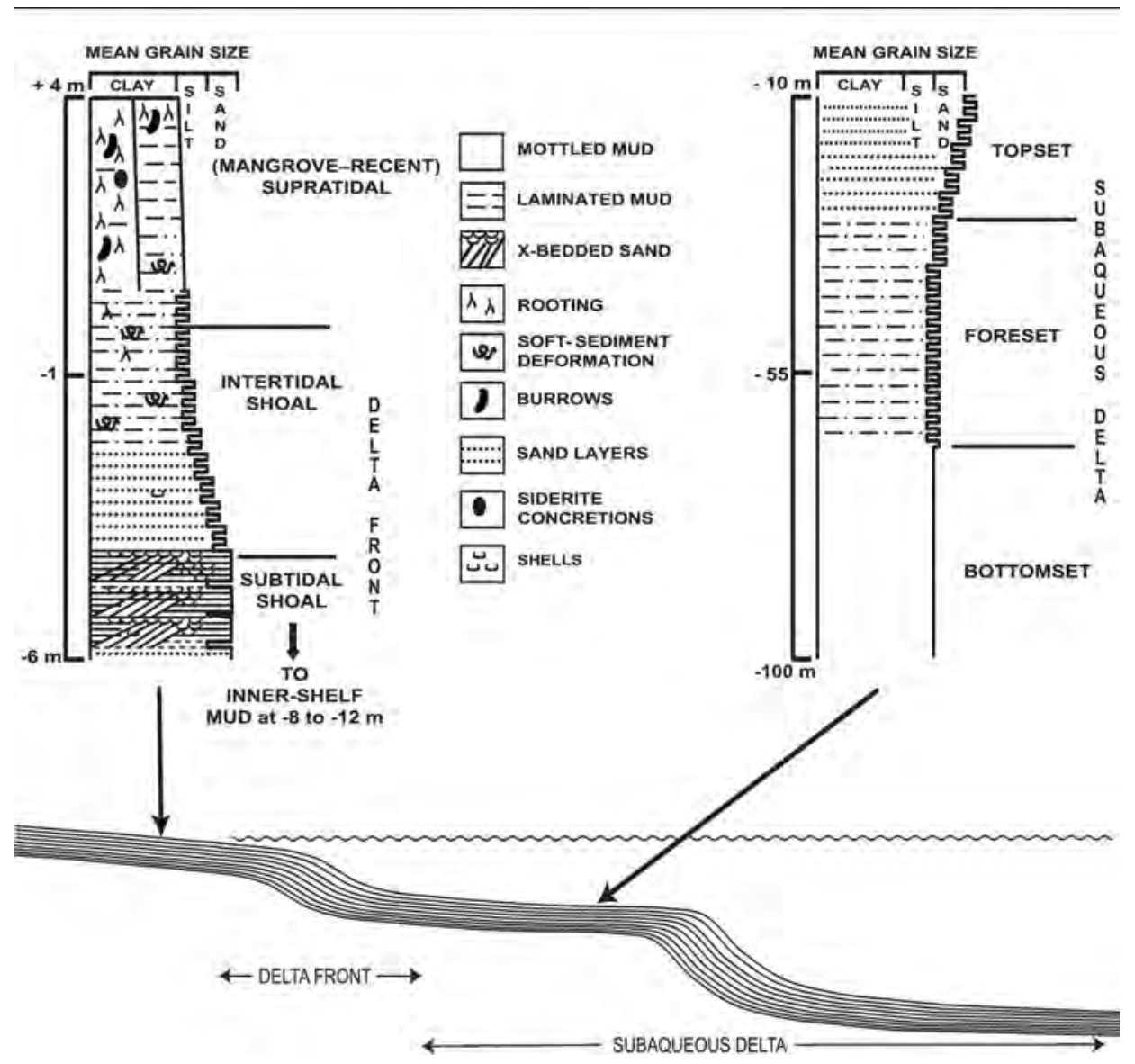

Fig. 5 Morphology of Geo-materials

Late quaternary sediments deposited, since the lowest stand of sea level during the last glacial maximum, in the Gangetic delta and its surrounding region were classified in five units according to their sedimentary facies. These are the lowest unit of sandy gravels, the lower unit of sand with a few grants and the middle, upper and uppermost units consisting mainly of sand and silt with occasional peat layers. The contact between the lower and middle units is fairly sharp, and the upper part of the lower unit is oxidized in some places (Umitsu, 1993). The 'khadar' deposits are as a rule confined to the vicinity of the present channels. The clays have less 'Kankar' and the organic remains. The 'Khadar' imperceptibly merges into the deltaic and other accumulations of the pre-historic times. The delta of Ganga-Brahmaputra is merely the sea ward prolongation of the 'Khadar' deposits of the respective river valleys. The total delta covers almost $1,30,00 \mathrm{~km}^{2}$ area composed of repeated alternations of clays, sands and marls with recurring layers of pit, lignite and some forest beds (Wadia, 1975). Physiography of the Floodplain

The river Bhagirathi, flowing from the north to south through the district, divides it into almost two equal portions; with a striking contrast to each other in terms of their geology, physical characteristics, agriculture and even religion of the inhabitants. The tract to the west of the river is locally known as 'Rarh', and the tract to the east as 'Bagri'- names which recall the traditional division of Bengal by King Ballal Sen. East of the Bhagirathi the country is low-lying and composed of alluvial deposits, with a humid climate and a fertile soil, which is liable to be flooded by the spill of the Bhagirathi and other rivers. On the western side the surface is high and undulating; the soil is hard clay, on which winter rice alone grows well and climate is drier than in the eastern tract. The Bhagirathi is more than a mere physical boundary, for west of it Hindus predominate, while on the east Musalmans are more numerous (O’ Malley, 1914). 

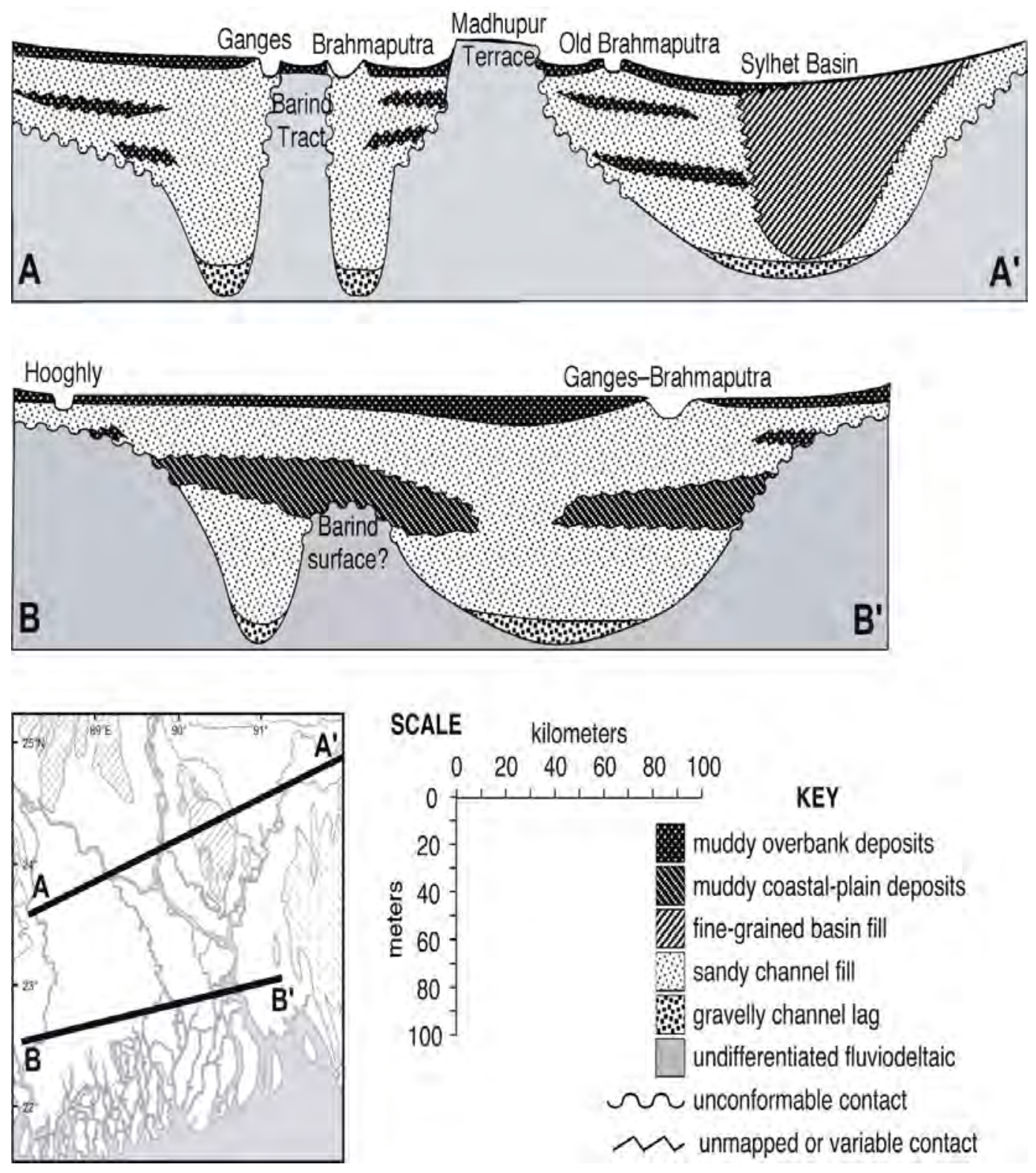

Fig. 6 Micro-Morphology of Geo-materials

The Bagri, or eastern tract, differs in no material respects from the ordinary alluvial plains of Bengal. It lies almost entirely between the Ganga, Bhagirathi and the Jalangi and is permeated by several other offshoots of the great river. The whole area lies low, and exposed to annual inundation, which occasionally causes widespread suffering and deposits over the land a top dressing of almost inexhaustible fertility. The two fold division of Murshidabad describe above is particularly interesting as furnishing a clue to the early formation and development of the western part of the Gangetic delta. There is no doubt that the present Bhagirathi represents the old channel of the river Ganga, by which the greater part of the water of the sacred river were formerly brought down to the sea. The most ancient tradition, the terraces of ruined cities, and the indelible record of names, all lead to this conclusion. The geological evidence proves to demonstration that the hard lateritic soil formed an insuperable obstacle to the Ganga flowing further to the west than the present course of the Bhagirathi, which is thus fixed as the limit of Bengal alluvium and the ancient means of communication between the Bay of Bengal and the interior. 


\section{Flood plain processes in the Bengal Delta}

Flood plain deposits are recognized as potentially large sinks for fluvial sediments. Yet spatial and temporal patterns of accumulation are not known for many river systems. In the tectonically active Bengal basin, the Ganges and Brahmaputra rivers have coalesced and have formed a large floodplain/delta, where widespread over bank flooding deposits a significant portion of the rivers estimated sediment discharge. To investigate the magnitude and distribution of process, accumulation rates were determined by $137 \mathrm{Cs}$ and $210 \mathrm{~Pb}$ radio isotope geochronology at 60 sites located in three regions of the Bengal Basin differing in age, physiography and river influence .Patterns of sediment deposition in the Bengal Basin reveal three dominant controls of floodplain accretion: channel process, overbank flooding and surface runoff. Accretion is most rapid in river braid belt and adjacent floodplain, decreasing rapidly with distance from the main channel. Accumulation rates increase again in low-laying distal basins, where several meters of annual precipitation and associate runoff rework surrounding floodplain surfaces and transport the sediments to local catchments. The extent and magnitude of this process indicate its comparable importance with overbank deposition for floodplain accumulation. A sediment budget for the study area reveals that at least $15 \%$ of the estimated 1 billion tonnes of fluvial sediment discharge is stored annually and does not reach the oceans as previously assumed (Goodbred and Kuehl, 1999).

\section{Changes in River Course Influences the Formation of the Floodplain}

The Gangetic delta, affords a striking example of the grand operations of nature produced by fluvial action. There can, as already pointed out, be no doubt that the present channel of the Bhagirathi, with its sacred traditions and early settlements, marks the ancient course of the Ganga, while that portion of the district which lies between the Bhagirathi and the present channel of the Ganga has been the scene of important river changes both before the dawn of history and within historical times. The whole of this area is scored with the tracks of old river beds, which represent the various channels scooped out by the water of the great river while they were being gradually diverted to their present course.

The whole process and the effect it has had in the formation of the land surface is well described by Dr. Thomas Oldham in an article published in the proceedings of the Asiatic Society of Bengal for 1870:"I" suppose no one will hesitate to acknowledge that the whole of the country lying between the Hooghly on the west and the Meghna on the east is only the delta caused by the deposition of the debris carried down by the rivers Ganga and Brahmaputra and their tributaries. It is also equally well known that in such flats the streams are constantly altering their courses, eating away on one bank and depositing on the other, until the channel in which they formerly flowed becomes choked up, and the water is compelled to seek another course.

It is also certain that, in this peculiar delta, the general course of the main waters of the Ganga has gradually tracked form the west towards the east, until, of late years, the larger body of the waters of the Ganga have united with those of the Brahmaputra, and have together proceeded to the sea as the Meghna. Every stream, whether large or small, flowing through such a float, tends to raise its own bed or channel by the deposition of the silt and sand it holds suspended in its waters, and by this gradual deposition the channel bed of the stream is raised above the actual level of the adjoining flats. It is impossible to suppose a river continuing to flow along the top of a raised bank, if not compelled to do so by artificial means, and the consequence of this filling in and raising of this bed is that, at the first opportunity, the stream necessarily abandons its original course, and seeks a new channel in the lower ground adjoining, until, after successive changes, it has gradually wandered over the whole flat and raise the entire surface to the same general level. The same process is then repeated, new channels are cut out, and new deposits formed.

The Bhagirathi formerly afforded a regular means of communication between the upper Gangetic valley and the sea-board, but ever since the British occupation of the country, much difficulty has been experienced in keeping it open for navigation throughout the year. There is ample evidence of the deterioration of the Bhagirathi in the next century. Stewart in his History of Bengal, which was chiefly compiled from the accounts of Muhammadan chroniclers, states that in 1757, just before the battle of Plassey, Siraj-ud-daula, "believing that the English ships of war might proceed up the eastern branch of the Ganges to the northern point of the Cossimbazar island and come down the Bhagirathi to Murshidabad, commanded immense piles to be driven in the river at Suti, by which the passage of that river has been rendered merely navigable by boats, and that only during half the year." 
In 1781 Rennell wrote that the Cossimbazar river (i.e, the bhagirathi) was almost dry from October to May, and that the Jalangi, although a stream ran through it the whole year, was in some years unnavigable during tow or theree of the driest months.Captain Colebrook, again in a memoir on the course of the Ganga (1797) wrote: "The Bhagirathi and Jalangi are not navigable throughout during the dry season. There have been instances of all these rivers continuing open in their turn during the dry season. The Jalangi used formerly to be navigable during the whole or greater part of the year. The Bhagirathi was navigable during the whole or greater part of the year. The Bhagirathi was navigable in the dry season of 1796.This year (1797), however, I was informed that the passage was no longer practicable for boats proceeding to Calcutta. Experience has shown that none of these rivers are to be depended on."
About the year 1813 the Bhagirathi suddenly deserted its old bed near Cossimbazar, and instead of following its former bed to the east of the town took a sweep to the west. Its old channel became a stagnant stretch of water, and the main stream flowed $5 \mathrm{~km}$ away from its former bed. The cause of this diversion of the channel is not known, but it may perhaps be surmised that it was connected with an attempt to introduce a larger supply of water down the channel by a cut across two bends. That there was some interference with the natural channel is clear from Hamilton's East India Gazetter of 1815, in which it is stated: "In 1813, a canal was dug between the Bhagirathi and great Ganges, partly to ameliorate the unhealthiness of the town (Murshidabad) and adjacent villages by maintaining a permanent stream of wholesome water".

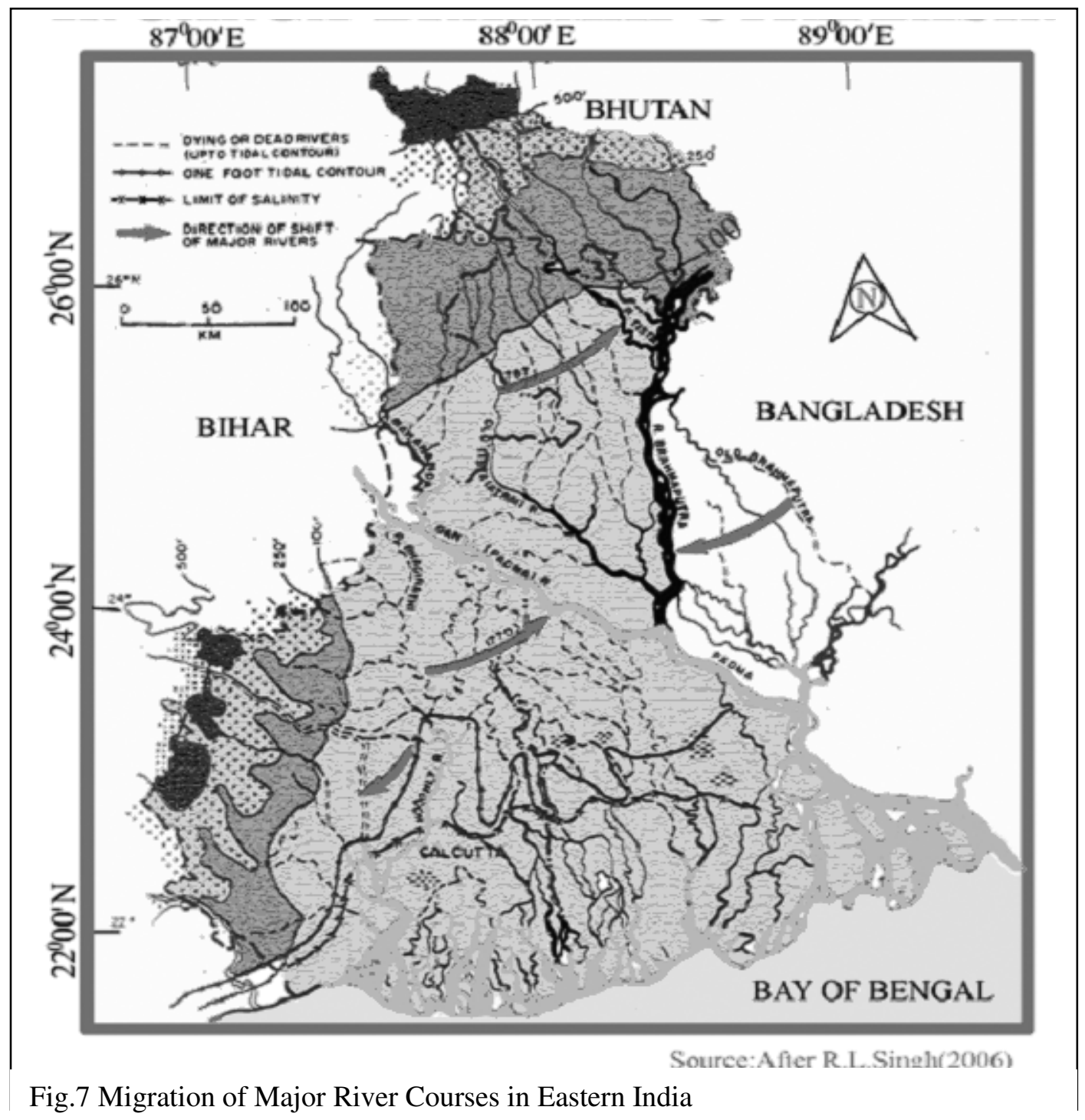


There is, moreover, a local tradition that a new channel was actually excavated, as stated by a writer in the Calcutta Review of 1873: "All these places (Cossimbazar and the adjacent villages)", he writes, "were originally situated on a curve of the river Bhagirathi, but seventy years ago a straight cut was made forming the chord of the curve, thus changing the course of the river. This engineering operation was followed by the breaking out of an epidemic fever, which, in virulence and mortality, is unparalleled by any pestilence save that which destroyed Gaur." The old channel survives as a 'khal', which is used by boats in the rains. It is curious that it is called Katigang as if it were an artificial channel, and there is a tradition that the Sahebs cut a channel and brought the river out to the north of Farasdanga.(O’ Malley, 1914.)

\section{Rocks \& Minerals of the Delta}

The sedimentology and mineralogy of the different parts of the basin reflect differences in sediment provenance. The mineralogy is dominated by detrital quartz, some feldspar and minor amounts of carbonates illite and kaolinite are the main clay minerals The basin has profuse groundwater resources, but the architecture of the aquifers is not yet well resolved. Different classification schemes have been proposed on the basis of lithology. Regional ground-water flow follows a low hydraulic gradient from north to south, but pumping for irrigation during the past several decades appears to have severely distorted regional flow. Recharge occurs primarily during the monsoon season. Ground-water chemistry is dominated by anoxic, $\mathrm{Ca}(\mathrm{HCO}) 2$ type water with relatively high concentration of $\mathrm{Fe}, \mathrm{Mn}$ and As. Carbonate dissolution, silicate weathering, $\mathrm{FeOOH}$ reduction and mixing with saline water are the primary processes controlling hydrochemistry (Mukherjee, Fryar and Thomas, 2007). The mainstream and various tributaries of the Ganges and Brahmaputra rivers drain a variety of geologic source rocks (Fig. 2). The highland streams of the Ganges largely drain Precambrian metamorphic rocks of the Himalaya southern slope, along with some PaleozoicMesozoic sedimentary sequences and Pleistocene alluvium. Lowland Ganges streams cross MesozoicTertiary flood basalts, Precambrian metamorphics, and Archean granites and gneisses. In contrast, the Brahmaputra basin is dominated by Mesozoic sandstone, shale, and limestone, with Precambrian acid intrusives and Cambrian sedimentary rocks.
The distinct geology of the two drainage basins leads to diagnostic differences in the mineralogy of modern sediments carried by the rivers (Heroy, 2002). For the fine sand fraction $(250-63 \mu \mathrm{m})$, the epidote-to-garnet ratio of Brahmaputra sediments is typically between 1.0 and 2.5, whereas ratios in Ganges sediments are $<$ 1 , with a typical value of about 0.5 . For the clay-size mineralogy, Brahmaputra sediment is characterized by higher relative abundances of illite $(63 \%$ vs. $41 \%)$, kaolinite (29\% vs. $17 \%$ ), and chlorite (2-3\% vs. $<1 \%$ ), whereas Ganges sediment contains significantly higher smectite (39\% vs.3\%). River waters of the Ganges and Brahmaputra contain a relatively high concentration of $\mathrm{Sr}(0.91 \mu \mathrm{mol} 1-1)$ with a higher radiogenic $87 \mathrm{Sr} / 86 \mathrm{Sr}$ ratio of 0.7295 than the global runoff. Therefore, the $\mathrm{Sr}$ input of the two rivers is considered to be a substantial source for the global Cenozoic increase of the seawater $87 \mathrm{Sr} / 86 \mathrm{Sr}$. Total dissolved salt concentrations are also relatively high compared to other major rivers$178 \mathrm{mg} \mathrm{1-1}$ in the Ganges and $100 \mathrm{mg} \mathrm{l-1}$ in the Brahmaputra-and are a result of chemical denudation rates 2-3 times higher than the world average created by high relief and high rainfall in the catchment. Combined total flux of dissolved ions to the oceans is $0.13 \times 1012 \mathrm{~kg}$ y-1 i.e. $3 \%$ of world total (Kuehl et al., 2005).

Analysis of mineralogy and statigraphic data indicates that the two rivers (Ganga and Brahmaputra) have changed their position several times during Holocene. Extended periods of mixed river inputs appear to be isolated to the Early Holocene, suggesting rapidly migrating braided channels during sea level lowstand (Heroy et al., 2002).

\section{Metals in the Delta}

The district is situated in the deltaic terrain. So, there is nochance of getting Metals stored within the silt bed. Here the source of metal is the sediment load or alluvium carried by the River Ganga and its tributaries during their flow from Chottanagpur plateau. The Ganga river sediment of the present study can be classified by Muller's geo-accumulation index as basically unpolluted with respect to these heavy metals. The concentration of $\mathrm{Cr}, \mathrm{Ni}$ and $\mathrm{Cu}$ was reported above the lowest effect level (LEL) that may have adverse effect on the Biogeochemistry at the river environment. The Ganga river transports $109 \times 10^{3}$ tons $\mathrm{Cr} ; 1313 \times 10^{3}$ tons $\mathrm{Mn} ; 30,020 \times 10^{3}$ tons Fe; $14 \times 10^{3}$ tons $\mathrm{Co} ; 35 \times 10^{3}$ tons $\mathrm{Ni} ; 41 \times 10^{3} \mathrm{Cu} ; 78 \times$ $10^{3}$ tons $\mathrm{Zn} ; 0.43 \times 10^{3}$ tons $\mathrm{Cd}$ and $16.4 \times 10^{3}$ tons $\mathrm{Pb}$ 
annually to the Bay of Bengal. The extensive physical weathering of the Himalayas and monsooncontrolled fluvial process results in the strong homogenization in heavy metal distribution in the river sediments (Singh et al., 2001). So the metal that existed with the Ganga river sediment should have been deposited in the delta during its genesis.

On the basis of Paleontological evidences, column of the Quaternary sediments of the Ganga basin as well as in the Ganga - Brahmaputra Delta has been constructed (Table-1).

The succession of the tertiary and Mesozoic rocks as suggested by Chatterjee (1964) or on the basis of the drilling report is presented information name "Jalangi 7" was given by geologists of 'Standard Vaccum Oil Company'.

The above section is considered as typical in character. The depth of the Mesozoic floor at Jalangi
(Murshidabad) is $3529 \mathrm{mt}$ below ground level. This indicates a tremendous thickness of tertiary sediments in the southern part of the delta. (Sarkar, 2001). The north -western and western parts of the district are slightly raised above the remaining portion , and are of older formation. The limits between the raised land and low alluvium is very distinctly marked in the north-west. The former presenting a bank of stiff clay, gravel, and nodular lime-stone ,elevated about fifteen or twenty feet above the low land. This bank would seem to mark the extreme western limits of Ganges River in older clays. To the South the bank is less marked, and soon vanishes altogether, the red ferruginous soil of Birbhum district here blends almost imperceptibly with low and later alluvium.

Thus the histogensis of the landforms influences largely to the human occupancy of this region and remains as a function of tectonic processes, changing river channels, sea level changes etc in this district.

Table 1: Quaternary Sediments in Lower Bengal

\begin{tabular}{|c|c|c|c|c|}
\hline System & Series & $\begin{array}{c}\text { Age (Million } \\
\text { Years) }\end{array}$ & Lithological character & Thickness (m.) \\
\hline \multirow{3}{*}{ Quarternary } & $\begin{array}{c}\text { Recent } \\
\text { (Holocene) }\end{array}$ & 0.01 & Sand, silt, clay & $91-189$ \\
\cline { 2 - 5 } & Pleistocene & 1.8 & $\begin{array}{c}\text { Sand, silt, Clay, Kankar } \\
\text { and Gravel }\end{array}$ & 1500 (approx) \\
\hline
\end{tabular}

After Sarkar, 2001

\section{Conclusion}

The tectonic evaluation of any landscape is made on the basis of hypothesis. The borehole data and the isopatch maps are treated as reliable data on which these predictions are made. Review and recheck of such data helps to get an idea of an area's tectonic background. If it is truly made then it helps to find out important rocks and minerals needed for human civilization. The tectonic evaluation of the terrain also helps to determine that whether the area is suitable for planning and development or not. It is undoubtedly said that the fertile Ganga-Brahmaputa delta is suitable for agricultural purposes but the low flat terrain is suitable for agro based industries also. The minerals can be achieved from the womb of it and can be filled up by the sands available here to maintain sustainability. The low flat terrain is enriched by ground water also, thus the people of this region will not suffer from scarcity of water. The only enemy of the deltaic region is the destructive flood. If the flood is controlled here in a sustainable manner then the world's largest delta will remain as one of the world's largest densely populated region for ever. 


\section{References}

Alam, M.(1989), Geology and depositional history of Cenozoic sediments of the Bengal Basin of

Bangladesh, Palaeogeography, Palaeoclimatology, Palaeoecology, Elsevier. doi:10.1016/0031-

0182(89)90159-4, v. 69, pp 125-139,

http://www.sciencedirect.com/science/journal/00310182 Alam, M.(1996), Subsidence of the Ganges-Brahmaputra delta of Bangladesh and associated drainage, sedimentation and salinity problems, Chapter-8, Sea-Level Rise and Coastal Subsidence; Causes, Consequences, and Strategies, Kluwer Academic Publishers, Dordrecht, ISBN0-7923-3933-9,The Netherlands, pp. 169-192.

http://www.books.google.co.in/books? isbn=0792339339 Alam, M., Alam, M.M., Curray, J.R., Chowdhury, M.L.R. and Gani, M.R.(2003), An overview of the sedimentary geology of the Bengal Basin in relation to the regional tectonic framework and basin-fill history, Sedimentary Geology,155,179-208. http://www.ees.uno.edu/Gani_Royhan/AlamEtAl2003.pdf Alam, M. (2005), Geology and Depositional History of Cenozoic Sediments of the Bengal Basin of Bangaladesh. Palaeogeography, Palaeoclimatology, Palaeoecology, 69, 125-139. doi:10.1016/0031-0182(89)90159-4, Online http://www.sciencedirect.com/science

Biswas, S.K., Agarwal, A.(1992),Tectonic Evolution of the Bengal Foreland Basin Since the Early Pliocene and its Implementation on the Development of Bengal Fan, in Recent Geoscientific studies in the Bay of Bengal and Andaman Sea, Geological Survey of India, Spl. Publication No.29, pp.5-19.

Goodbred Jr., S.A. and Kuehl, S.A. (1999), Holocene and modern sediment budgets for the Ganges- Brahmaputra river system: Evidence for highstand dispersal to flood-plain, shelf, and deep-sea depocenters, Geology; June 1999, GSW Publications, USA, DOI: 10.1130/0091-

7613(1999)027, v. 27; no. 6; pp. 559-562; geology.geoscienceworld.org/cgi/reprint/27/6/559.pdf Goodbred Jr, S. L, Kuehl, S. A. (2000), The significance of large sediment supply, active tectonism, and eustasy on margin sequence development: Late Quaternary stratigraphy and evolution of the Ganges-Brahmaputra delta, Sedimentary Geology,Elsevier Science B.V, Copyright (C) 2000, Issues 3-4,v.133,pp. 227-248 http://www.sciencedirect.com/science/journal/00370738. Heroy, D.C., Kuehl, S.A. and Goodbred, S. L. (2002), Mineralogy of The Ganges and Brahmaputra Rivers: Implementations For Rivers Shifting And Late Quaternary Climate Change. Sedimentary Geology 155(2-3), 343-359. Available Online doi: 10.1016/S0037- 0738(02)00186-0, Imam, M.B.and Shaw, H.F.(1987), Diagenetic controls on the reservoir properties of gas bearing Neogene Surma Group sandstones in the Bengal Basin, Bangladesh,
Marine and Petroleum Geology, doi:10.1016/02648172(87)90026-2, www.sciencedirect.com/science /article/pii/ 0264817287900262

Kuehl, S.A., Allison, M. A. Goodbred, S. L. and Kudrass, H. (2005), The Ganges-Brahmaputra Delta,SEPM Special Publication No. 83(Society for Sedimentary Geology), ISBN 1-56576-113-8, pp. 413-434. www.vims.edu/people/kuehl_sa/pubs/SEPMG-B Delta.pdf

Mukherjee, A., Fryar A. E. and William, A. T. (2008), Geologic, Geomorphic and Hydrologic Frame Work and Evolution of the Bengal Basin, India and Bangladesh, Journal of Asian Earth Sciences, 34( 3), 227-244.

AvailableOnline 8june,2008.

http://linkinghub.elsevier.com/retrieve/pii/S136791200800 $\underline{093 X}$

Neogi, B.B., Srivastava, U.C. and Badhe, S. (1987)

Subsurface Geology of Bengal Basin with Reference to Stratigraphy, Facies, Geological History and Reappraisal of Hydrocarbons plays, ONGC Unpublished report O' Mally, L.S.S. (1914), Rivers of Bengal, Bengal District Gazetteers, pp.1-25, pp.97-154, and pp.177-204.

Reimann, K.U. and Hiller, K.( 1993), Geology of

Bangladesh. Beiträge zur regionalen Geologie der Erde (Series) no. 20, Geological Magazine (1995). Cambridge University Press 1995, ISBN 344311020 7,DOI: 10.1017/ S0016756800019130 Sarkar, B.

(2001), South 24 Parganas, A study in coastal

Geomorphology, Ph.D.Thesis, Visva-Bharati University,

Santiniketan, pp.21-25.

Singh, M., Muller and Singh, I.B. (2003), Geogenic Distribution and Baseline Concentration of Heavy Metals in Sediments of the Ganges River India. Journal of Geochemical Exploration, 80(1), 1-17. doi:10.1016/S0375-6742(03)00016-5, Uddin, A. and Lundberg, N. (2003), Miocene Sedimentation and Subsidence during Continent Collision, Bengal Basin, Bangladesh. Sedimentary Geology, 164, 131-145. doi:10.1016 Availableonline www.auburn.edu/academic/science_math/.../miocene $\% 20$ sedimentation.pdf Umitsu, M. (1993), Late Quaternary Sedimentary Environments and Landforms in the Ganga Delta, Sedimentary Geology, 83(3-4), 177-186. doi:10.1016/0037-0738(93)90011-S Available online http://linkinghub.elsevier.com/retrieve/pii/0037073893900 $\underline{11 \mathrm{~S}}$

Wadia, D.N. (1975), Geology of India, Tata Mc Graw Hill. pp.1-3, pp.381-85. 